\title{
APLiKaSi Karakteristik ArsitekTUR FUTURISTIK Pada Terminal Penumpang Pelabuhan Yos Sudarso Di Kota AMbON
}

\author{
Ekine Wahyuning Tyas ${ }^{1 *}$, Agung Kumoro Wahyu W' ${ }^{2}$, Widi Suroto ${ }^{3}$ \\ Program Studi Arsitektur, Fakultas Teknik, Universitas Sebelas Maret ${ }^{1}$ \\ *Email : florentina.tyas@gmail.com* \\ Program Studi Arsitektur, Fakultas Teknik, Universitas Sebelas Maret ${ }^{2}$ \\ Program Studi Arsitektur, Fakultas Teknik, Universitas Sebelas Maret ${ }^{3}$
}

\begin{abstract}
Maluku as one of the archipelago provinces in Indonesia would require a sea transportation system to improve movement of goods and services inter-islands both within and outside of the Province. Ambon City as the capital of Maluku Province has an important role in accommodating it . Ambon City itself currently has six ports with different functions. One of the main ports is the Port of Yos Sudarso Ambon which currently accommodates two functions. First, as a port of passenger and second as a container port. However, along with the increasing container demand and inadequate port area. Then, there are various proposals which proclaimed in various regional and national development programs to focus on the transition function of Yos Sudarso Port in accommodating the activities of departure and arrival of passengers and eliminate the function of containers activity. The futuristic architectural approach is intended to find the need for architectural masterpieces of modern character and stand out along the Ambon Waterfront City development area. This approach represents progress, something new that is different from the other building on the environment and speed points which is identical with building of transportation. So it is expected that through this approach can be generated a redesign concept that can provide first impression for its users.
\end{abstract}

Keyword : Port, Passanger Terminal, Futuristic Architecture, Transportation Building

\section{PENDAHULUAN}

Moda transportasi laut di Provinsi Maluku saat ini masih menjadi primadona dan dinilai sangat penting bagi pergerakan perekonomian karena efisiensinya yang dapat menjangkau pulau-pulau terkecil diluar maupun didalam Provinsi Maluku itu sendiri yang tidak dapat dijangkau oleh moda transportasi lain. Kemampuan daya beli masyarakat juga menjadi faktor pendorong terpilihnya moda transportasi laut sebagai sarana utama moda transportasi di Provinsi ini. Dalam hal ini, Kota Ambon sebagai Ibukota Provinsi Maluku tentu memiliki nilai strategis dalam hal ekonomi, sosial, hukum, pariwisata serta kebudayaan. Dan tentu saja memiliki tingkat kepadatan, pendapatan daerah, upah minimum, kesediaan sarana-prasarana serta jumlah populasi sebagai faktor penyumbang jumlah penumpang pengguna angkutan laut tertinggi dibandingkan dengan Kota dan Kabupaten lain didalam Provinsi Maluku. Namun sayangnya, penyedia jasa fasilitas transportasi laut seperti terminal penumpang belum dikelola dengan maksimal. Terminal penumpang yang ada saat ini hanya dapat menampung 800 hingga 1000 calon penumpang, sedangkan dalam sekali proses debarkasi dan embarkasi penumpang yang berlangsung pada satu kapal dengan bobot 2000 gros ton, terdapat 500 hingga 2000 calon penumpang yang seharusnya dapat diwadahi oleh terminal tersebut. Jika terdapat dua atau lebih kapal bersandar (bertambat) dan melakukan proses bongkar muat penumpang secara bersamaan, maka dapat dipastikan tidak semua calon penumpang dapat terwadahi didalam terminal/ruang tunggu. Sehingga menyebabkan overload sampai di bagian dermaga dan apron pelabuhan. Terminal penumpang pada pelabuhan ini sudah beroperasi cukup lama sehingga sampai dengan saat ini masih menjadi satu-satunya Pelabuhan Kelas I 
di Kota Ambon dan sudah berkali-kali mengalami perluasan lahan, hanya saja fasilitas yang tersedia masih dapat dikatakan belum terolah dengan maksimal. Permasalahan utama yang dihadapi pada terminal penumpang ini adalah kondisi dimana tidak tersedianya ruang yang cukup didalam terminal penumpang sehingga calon penumpang yang tidak dapat tertampung didalam ruang tunggu terpaksa menunggu dan berdesakan diluar gedung terminal. Selain daripada itu, aplikasi karakteristik arsitektur futuristik yang digunakan lebih dilatarbelakangi oleh kebutuhan suatu karya arsitektural yang dapat mengatasi kejenuhan, identik dengan kecepatan dalam mengakses suatu tujuan sesuai dengan kaidah utama banguna transportasi, berkarakter kuat serta berorientasi pada kemajuan masa depan untuk mendukung keberadaan Pelabuhan Yos Sudarso itu sendiri didalam kawasan area pengembangan Ambon Waterfront City.Kebutuhan desain yang inovatif, baru, modern serta tidak monoton dianggap tepat untuk mengatasi kejenuhan desain dan menghasilkan suatu karya iconic, representatif dan unik untuk menarik perhatian penggunanya. Sehingga melalui aplikasi karakteristik arsitektur pada bangunan tersebut dapat menjadikan terminal penumpang Pelabuhan Yos Sudarso menjadi "kenangan pertama" dan "welcome gate" yang berkesan bagi penggunanya terutama bagi yang memanfaatkan moda transportasi laut untuk menjangkau Kota Ambon itu sendiri.

\section{METODE}

Metode yang digunakan dalam proses redesain adalah penguraian terhadap aplikasi karakteristik arstektur futuristik yang tertera didalam buku Futurism An Anthology, 2009 oleh Antonia Sant'Elia. Karakter tersebut diantaranya :

- Arsitektur futuristik memerlukan perhitungan matang, keberanian/tekad yang kuat untuk mencapai nilai keelastisan dan keringanan yang maksimum

- Arsitektur futuristik tidak hanya memperhatikan kepraktisan dan kegunaan semata melainkan juga memperhatikan seni ekspresi pada tampilannya
- Arsitektur futuristik lebih memanfaatkan tipe garis-garis miring dan elips untuk menciptakan unsur dinamis

- Arsitektur futuristik tidak menggunakan seni ornamentasi didalam bangunan untuk mengekspresikan suatu bentuk yang dikehendaki

- Arsitektur futuristik merupakan kunci perubahan untuk menemukan inspirasi yang baru baik secara material maupun spiritual

- Arsitektur futuristik harus dipahami sebagai upaya yang diimplementasikan dengan kebebasan dan keberanian serta menyelaraskan manusia dan lingkungannya

Oleh karena itu, pada redesain terminal penumpang Pelabuhan Yos Sudarso yang baru, aplikasi karakteristik arsitektur futuristik diterapkan pada :

a. Tapak

Untuk mengatasi pencapaian, memaksimalkan potensi, meminimalkan kendala yang terdapat pada site, kondisi alam yang berkaitan, peraturan bangunan yang seharusnya dipenuhi sebagai unsur utama keberadaan Pelabuhan Yos Sudarso dan mendukung kawasan dengan bangunan itu sendiri

b. Program ruang

Untuk mendapatkan besaran luas kebutuhan ruang yang seharusnya dapat terwadahi dan menjawab permasalahan kebutuhan pengguna terminal penumpang Pelabuhan Yos Sudarso berdasarkan pada pengguna dan program kegiatan yang diwadahi serta tidak membingungkan penggunanya

c. Tampilan fisik

Untuk menghasilkan tampilan fasad yang bangunan yang memiliki kriteria-kriteria tertentu bagi pengguna dan penikmatnya serta dapat beradaptasi dengan existing site yang sudah diterapkan.

d. Struktur dan Utilitas

Untuk mendukung keberadaan bangunan terminal penumpang serta kawasan Pelabuhan Yos Sudarso Ambon dalam memfasilitasi pengguna dan aktivitas didalamnya.

\section{ANALISIS}
a. Tapak 


\section{Site terpilih dan batasannya}

Sesuai dengan Peraturan Tata Ruang Wilayah Kota Ambon, eksisting Pelabuhan Yos Sudarso sudah ditetapkan berdasarkan regulasi-regulasi yang berlaku. Site terpilih merupakan site yang sudah digunakan sebelumnya. Sehingga prosentase redesain mencapai $100 \%$ kawasan yakni sebesar $388.388 \mathrm{~m}^{2}$. Site berupa tanah yang dikuasai oleh Negara dan dijelaskan didalam Pasal 2 ayat 2 UU No. 5 Tahun 1996 serta dikelola oleh PT. Pelindo IV.

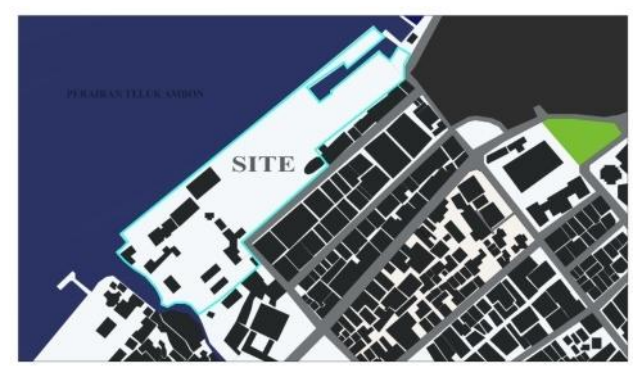

Gambar 1. Eksisting Site Pelabuhan Yos Sudarso Ambon

Site terpilih terletak di JL. Pelabuhan Yos Sudarso No. 1 Ambon, Provinsi Maluku. Dengan koordinat $3^{\circ} 41^{\prime} 31^{\prime \prime} \mathrm{LS} / 128^{\circ} 10^{\prime} 28^{\prime \prime} \mathrm{BT}$ dan kedalaman kolam dermaga mencapai $13 \mathrm{~m}$ LWS. Sisi Barat eksisting site berbatasan dengan pemukiman penduduk, Sisi Timur berbatasan dengan Perairan Teluk Ambon, Sisi Selatan berbatasan dengan kompleks pertokoan dan Sisi Utara berbatasan dengan JL. Pelabuhan Yos Sudarso.

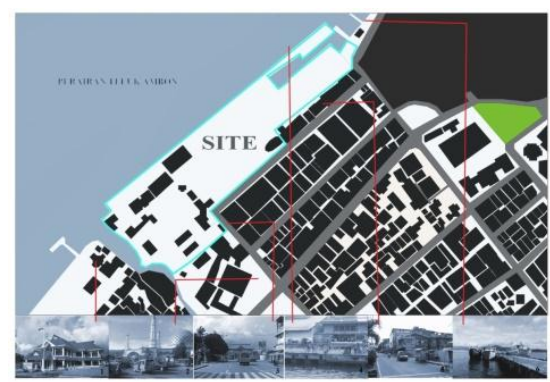

Gambar 2. Batas-batas pada Eksisting Site

\section{Pencapaian menuju site}

Analisa pencapaian menuju site bertujuan untuk menentukan posisi paling berpotensi untuk mendukung kelancaran sirkulasi dari dan menuju Pelabuhan Yos Sudarso. Analisa didasarkan atas faktor fleksibilitas, fiesibilitas serta kecepatan mencapai eksisting Pelabuhan. Hal ini dilakukan untuk mempermudah calon penumpang dalam mengakses Pelabuhan tanpa merasa dibingungkan oleh kondisi yang ada. Pencapaian menuju site juga mempertimbangkan jenis jalan yang akan dilalui disekitar site serta kelancaran dan kesediaan transportasi umum.

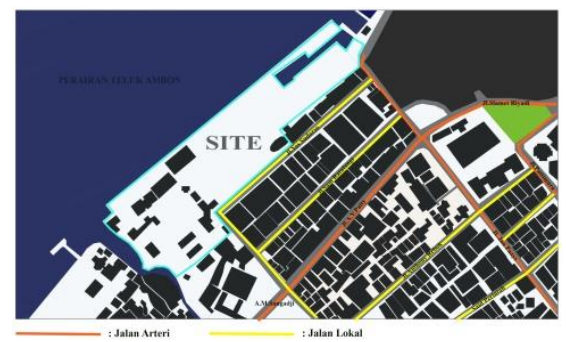

Gambar 3. Jenis Jalan yang terdapat disekeliling eksisting site

Berdasarkan jenis jalan yang terdapat disekitar site eksisting serta jaminan kesediaan jenis transportasi umum darat sebagai media penghubung dan juga berdasarkan faktor-faktor yang telah dijabarkan, maka pencapaian menuju site dapat diakses melalui Daerah A.M. Sangadji (Kemungkinan 1) bagi pengguna yang berasal dari Sisi Utara Eksisting, Jl. Jan Paays (Kemungkinan 2) bagi pengguna yang berasal dari Sisi Barat Eksisting serta Jl. Pala (Kemungkinan 3) bagi pengguna yang berasal dari Sisi Selatan Eksisting. 


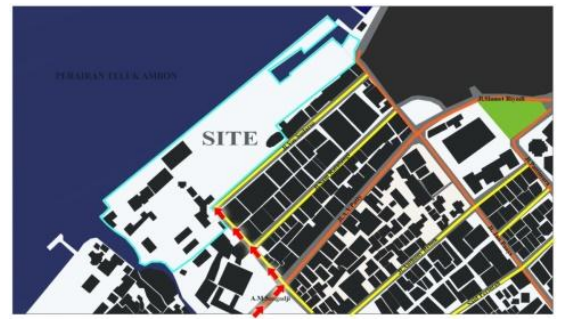

Gambar 4. Ilustrasi Kemungkinan I

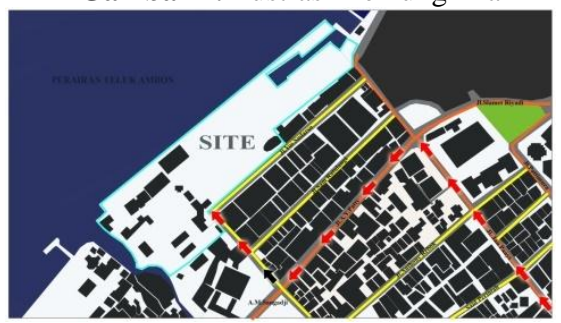

Gambar 5. Ilustrasi Kemungkinan II

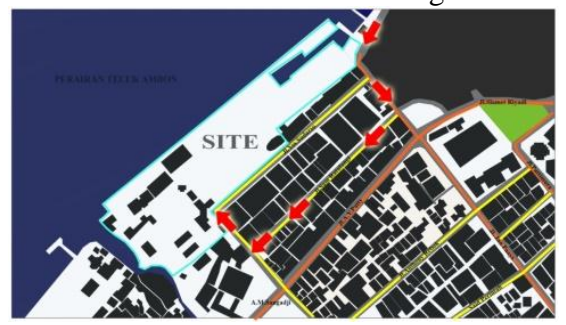

Gambar 6. Ilustrasi Kemungkinan III

b. Potensi dan View pada Site

Analisa view pada eksisting bertujuan untuk mengetahui potensi view yang terdapat pada eksisting. Analisa ini berkaitan erat dengan kesan estetik suatu lingkungan maupun bangunan karena view yang baik seharusnya dapat memperlihatkan nilai estetik dari luar ke kawasan dan sebaliknya. Selain daripada hal tersebut, eksisting site memiliki potensi kecinderungan kontur tanah yang datar, luasan memadai, dikelilingi oleh fasilitas-fasilitas umum penunjang.

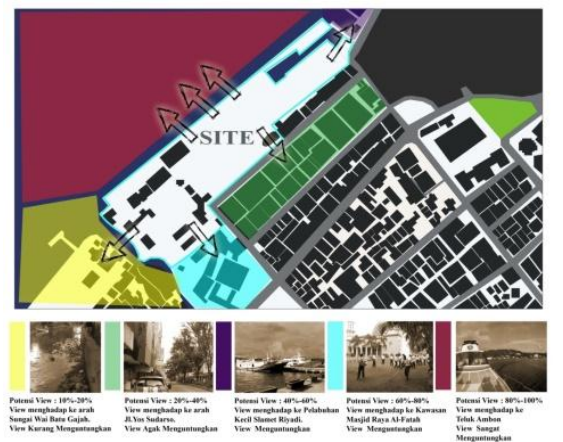

Gambar 7. Ilustrasi View dari dalam kawasan pelabuhan ke luar kawasan pelabuhan

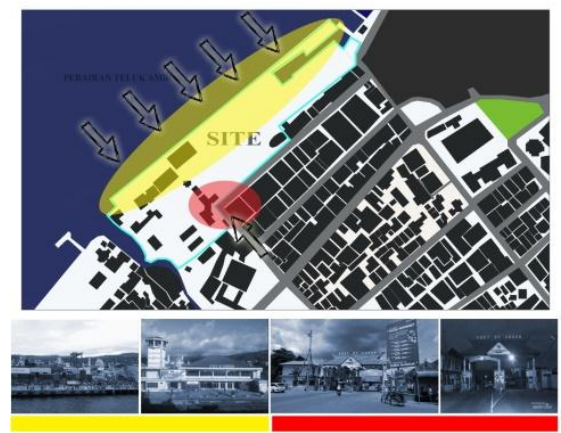

Gambar 8. Ilustrasi view dari luar kawasan pelabuhan ke dalam kawasan pelabuhan

Berdasarkan analisis yang dilakukan, maka dapat disimpulkan bahwa sisi barat dan timur memiliki potensi yang besar untuk dijadikan sebagai fasad utama bangunan untuk menarik perhatian pengunjung, dijadikan sebagai identitas kawasan kepelabuhan, serta representatif dan unik untuk menjadi bagian didalam kawasan Ambon Waterfront City. Sisi barat merupakan sisi entrance pelabuhan bagi penumpang embarkasi moda transportasi laut sedangkan sisi timur merupakan sisi welcome bagi penumpang debarkasi moda transportasi laut.

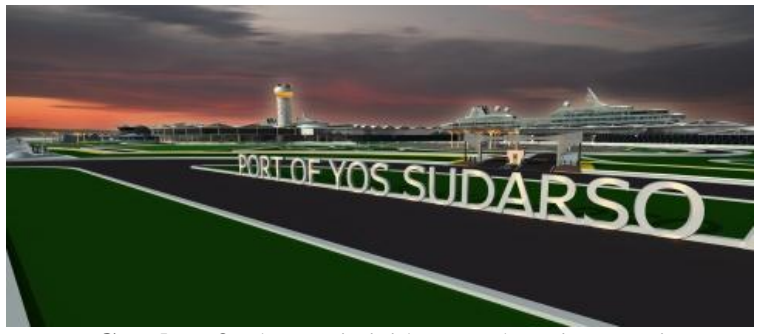

Gambar 9. Ilustrasi sisi barat sebagai potensi pengembangan area main entrance

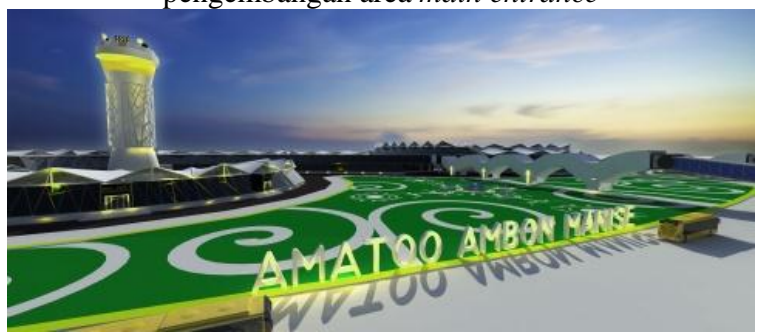

Gambar 10. Ilustrasi sisi timur sebagai potensi pengembangan welcome area

c. Kendala dan Kekurangan

Kendala yang terdapat pada eksisting site adalah berupa kurangnya daerah resapan air sehingga menyebabkan genangan air berlebihan saat memasuki musim penghujan yang mempengaruhi kelancaran serta kenyamanan pengguna yang akan mengakses pelabuhan. 
Selain itu juga terdapat kendala berupa pencemaran minyak dan juga pencemaran sampah pada area sekitar eksisting. Baik yang berasal dari dalam maupun luar pelabuhan. Hal tersebut tentu mempengaruhi munculnya parasit seperti tikus yang dapat merugikan pengguna jasa kepelabuhan. Pencemaran lain yang perlu diperhitungkan adalah pencemaran udara yang kemungkinan mengandung jelaga/asap hitam, debu serta konsentrasi sulfur dioxide, nitrogen dioxide, carbon monoxide dan Hydrocarbon yang dapat mengganggu metabolisme pengguna jasa kepelabuhan.

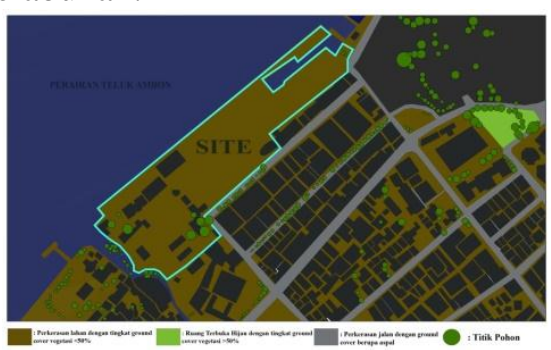

Gambar 11. Ilustrasi perbandingan antara lahan terbuka hijau dengan perkerasan lahan vegetasi $<50 \%$

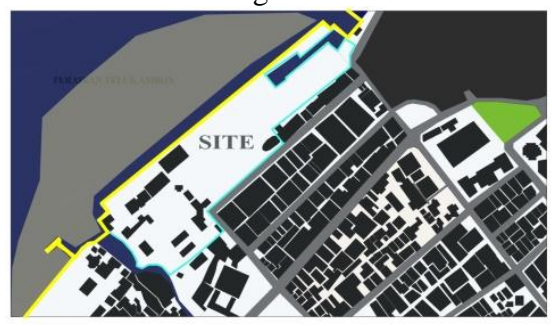

Gambar 12. Ilustrasi Daerah Tercemar Limbah Minyak pada Kolam Pelabuhan Yos Sudarso (Arsir Kuning)

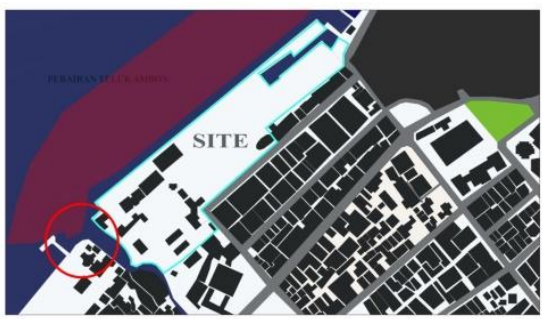

Gambar 13. Ilustrasi Titik Pertemuan antara Perairan Teluk Ambon dengan Singai Wai Batu Gajah dan daerah tercemar limbah sampah pada Kolam Pelabuhan Yos Sudarso (Arsir Merah)
Kekurangan daerah resapan pada eksisting site dihadapi dengan pengadaan ruang terbuka yang mencukupi dan disesuaikan dengan luasan yang dihasilkan atas perhitungan terhadap peraturan bangunan dan kawasan yang berlaku di Kota Ambon. Sedangkan untuk masalah sampah yang berasal dari Sungai Wai Batu Gajah di sisi utara eksisting dapat diatasi dengan memasang alat perangkap sampah di hulu sungai sehingga sampah tidak menyebar sampai di dermaga Pelabuhan.

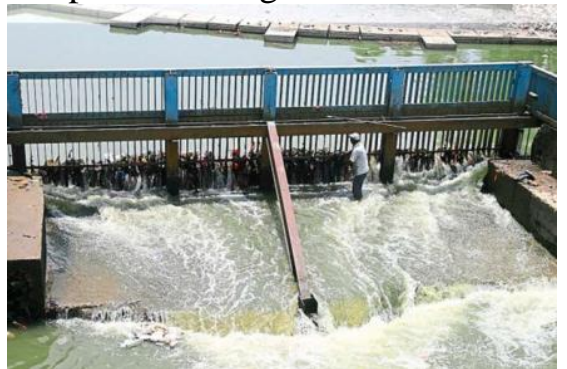

Gambar 14. Aplikasi perangap sampah pada perairan

(Diakses dari http://www.thestar.com.my Pada 16 Juli 2017 pukul 10:00)

Untuk masalah pencemaran minyak, dapat diatasi dengan memasang instalasi atau rekayasa struktur pada bagian dermaga dengan memasang Oil Water Separator Operating yang dapat memisahkan air dari limbah laut secara mekanik.

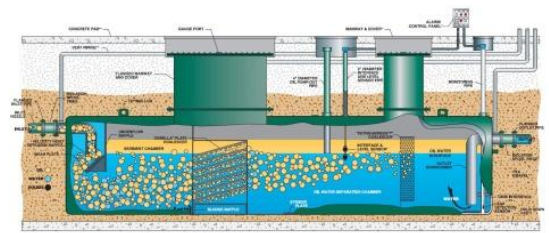

Gambar 15. Ilustrasi Oil Water Separator Operating

(Diakses dari http://gandras.netPada $16 \mathrm{Juli}$ 2017 pukul 10:18)

Selain itu, untuk mengatasi pencemaran udara yang mungkin terjadi. Maka penanaman vegetasi pada area lansekap untuk membantu memfilter udara secara alami akan menjadi jawaban pasti 
atas kekurangan yang ada pada eksisting.

d. Pergerakan Matahari dan Kondisi Angin

Analisa ini bertujuan untuk menentukan posisi letak penghawaan alami pada bangunan, mengetahui perlu tidaknya suatu barrier untuk mengahalangi potensi angin berlebih, pemilihan material, penataan bentuk massa bangunan, mempertimbangkan bukaan untuk mendapatkan pencahayaan alami, serta memprediksikan potensi bayangan yang dapat memberikan efek teduh pada eksisting.

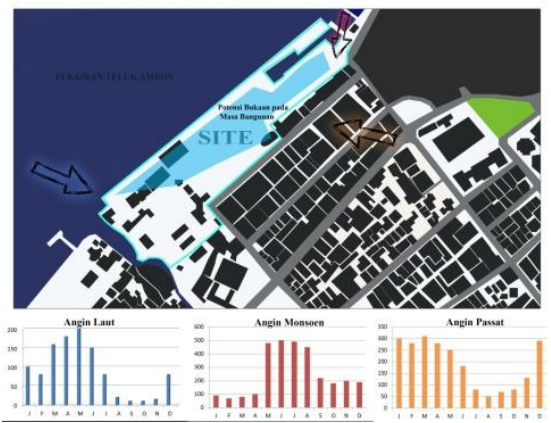

Gambar 16. Ilustrasi Arah datangnya angin pada Kawasan Pelabuhan Yos Sudarso Ambon

Eksisting site dipengaruhi oleh tiga jenis angin sekaligus yang berhembus hampir ditiap waktu dalam satu tahun berjalan. Jenis angin tersebut adalah jenis Angin Laut, Angin Monsoen dan Angin Passat. Dalam kondisi normal, angin yang berhembus pada eksisting mencapai kecepatan 6 knot. Pada skala Beaufort, kecepatan ini meruakan kecepatan skala 2 yang artinya potensi agin agak kencang.

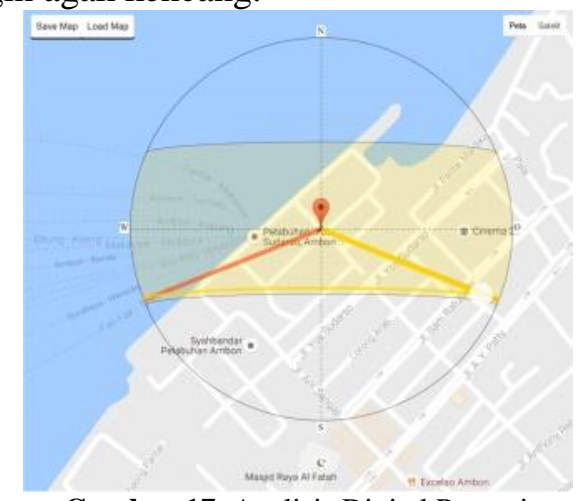

Gambar 17. Analisis Digital Potensi Penyinaran Matahari
Karena letaknya yang berada di pesisir pantai, tentu saja eksisting memiliki potensi penyinaran alami berlebih. Dengan puncak penyinaran berada pada pukul 10:17 pagi dan mengalami durasi penyinaran dalam setengah hari mencapai 12.18 jam. Panjang bayangan pada objek didalam site yang memiliki ketinggian 1 meter mampu mencapai 2.15 meter. Maka, jika ketinggian bangunan terminal penumpang yang direncanakan mencapai 12 meter. panjang bayangan dihasilkan dapat mencapai 25.8 meter dari sisi pencahayaan yang berasal dari sudut Alzimuth.

Melihat potensi angin yang ada, disimpulkan bahwa posisi letak penghawaan alami pada bangunan dapat tersebar diseluruh sisi bangunan. Letak penghawaan ini diaplikasikan melalui aplikasi system porous wall maupun melalui ventilasi udara pada bangunan.

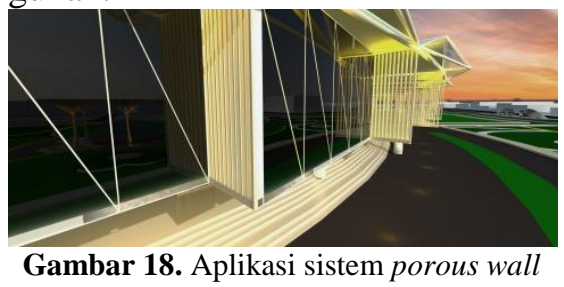
atau dinding berpori pada desain

Dalam hal ini juga, tidak diperlukan adalah barrier yang berlebih didalam bangunan untuk menghalangi potensi angin. Namun, mengingat kecepatan angin yang cukup besar yang dapat mengenai bangunan secara langsung maka penarapan sistem opposite ventilationpada bangunan dinilai menguntungkan.

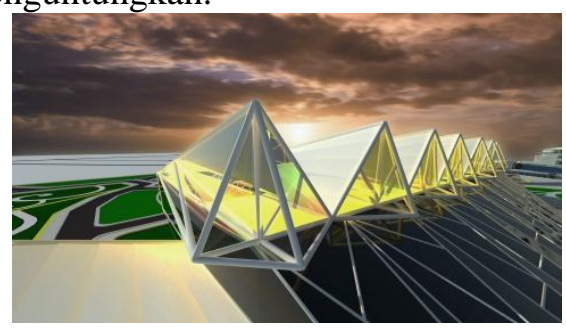

Gambar 19. Aplikasi sistem opposite ventilation pada desain

Sistem ini akan langsung meneruskan angin yang masuk, menjadi langsung keluar dari multiple opening yang ada. 
Sedangkan barrier kawasan untuk mengatasi angin berlebih akan diatasi melalui vegatasi padalansekap. Shape masa yang halus dapat membantu meloloskan angin yang berlebih. Oleh karena itulah, masa bangunan di dalam eksisting didominasi oleh lekukanlekukan halus yang dinamis.

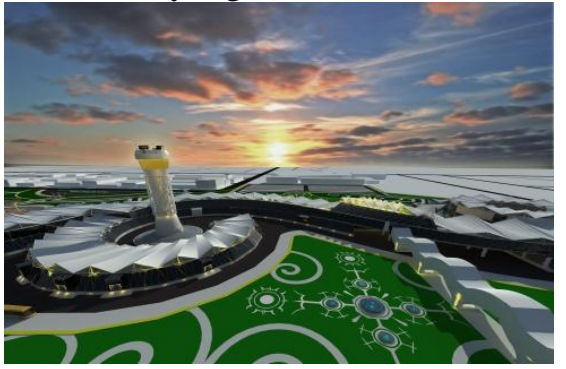

Gambar 20. Aplikasi shape halus pada desain untuk memunculkan kesan dinamis Ketinggian bangunan yang mencukupi serta sesuai dengan kebutuhan yang ada tentu akan mempengaruhi pembayangan yang dihasilkan. Oleh karenanya, hasil pembayangan tersebut dapat digunakan sebagai efek peneduh yang berpotensi mengurangi efek thermal yang ada.

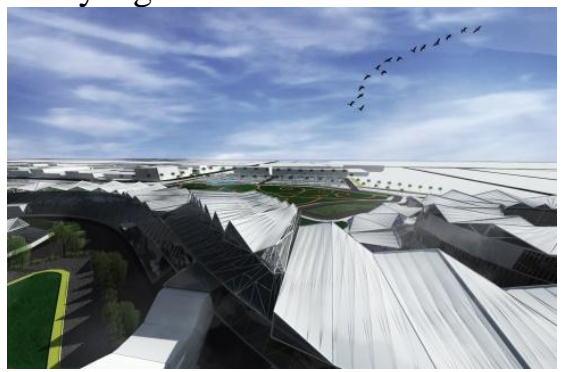

Gambar 21. Ilustrasi pembayangan pada desain

Sedangkan untuk bukaan didalam bangunan, akan dimanfaatkan voidvoid untuk membantu meloloskan pencahayaan alami didalam bangunan sehingga dapat menghasilkan efek megah dan luas dengan menggunakan prinsip light shelf dan light well.

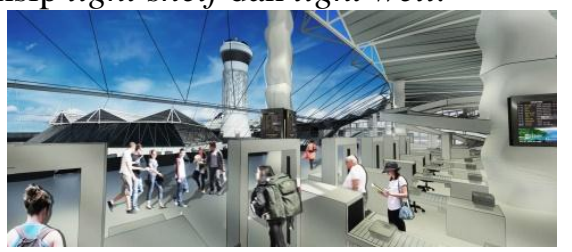

Gambar 22. Aplikasi prinsip light shelf pada desain

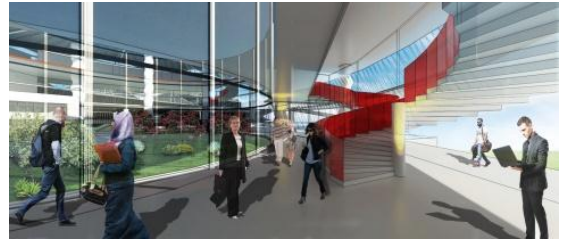

Gambar 23. Aplikasi prinsip light well pada desain

e. Regulasi Bangunan yang berlaku

Analisis simulasi perhitungan besaran koefisien bangunan dan yang lainnya dibutuhkan untuk memperjelas batasan wajar atas luasan bangunan dan kawasan yang diperbolehkan untuk dibangun berdasarkan dengan regulasi bangunan yang berlaku demi menghidari penyalahgunaan lahan dimasa mendatang.

a. Luas total lantai dasar yang diperbolehkan berdasarkan KDB

Lbd : $388.388 \mathrm{~m}^{2}$ x $40 \%$

$$
: 155.355,2 \mathrm{~m}^{2}
$$

b. Luas lantai dasar terbuka: $10 \% \mathrm{x}$ Lbd

: $10 \%$ x $155.355,2 \mathrm{~m}^{2}$

$: 15.535,52 \mathrm{~m}^{2}$

c. Luas lantai dasar tertutup: \{Lbd (luas lantai dasar terbuka x 50\%) \}

: $\left\{155.355,2 \mathrm{~m}^{2}-(15.535,52\right.$ $\left.\left.\mathrm{m}^{2} \times 50 \%\right)\right\}$

$:\left\{155.355,2 \mathrm{~m}^{2}-7.767,76 \mathrm{~m}^{2}\right\}$ : $147.587,44 \mathrm{~m}^{2}$

d. Luas total lantai dasar: Luas lantai dasar terbuka + luas lantai dasar tertutup

$$
\begin{aligned}
& : 15.535,52 \mathrm{~m}^{2}+147.587,44 \mathrm{~m}^{2} \\
& : 163.122,96 \mathrm{~m}^{2}
\end{aligned}
$$

e. Total luas lantai terbangun: Lbd + (kemungkinan jumlah sisi bangunan $\mathrm{x}$ kemungkinan lebih luas lt atas dibanding lt bawah)

: $\mathrm{Lbd}+(14 \times 1,5)$

: $155.355,2 \mathrm{~m}^{2}+21$

: $155.376,2 \mathrm{~m}^{2}$

f. RTHP (Ruang terbuka hijau pekarangan): Lp x KDH

: $388.388 \mathrm{~m}^{2}$ x $40 \%$

$: 155.355,2 \mathrm{~m}^{2}$

Luas fasilitas terbuka (pedestrian, parkir, sirkulasi kendaraan dan perkerasan lain) 


$$
\begin{aligned}
& \text { : Lp - Luas Total Lantai Dasar - } \\
& \text { RTHP } \\
& : 388.388 \mathrm{~m}^{2}-163.122,96 \mathrm{~m}^{2}- \\
& 155.355,2 \mathrm{~m}^{2} \\
& : 69.909,84 \mathrm{~m}^{2}
\end{aligned}
$$

Berdasarkan analisis yang sudah dilakukan maka dapat disimpulkan peruntukan besaran lahan yang harus diolah pada eksisting site mencapai :

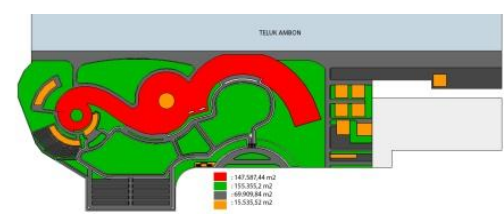

Gambar 24. Ilustrasi Hasil Analisa Keseluruhan Persayaratan terhadap site

\section{f. Main Entrance dan Side Entrance}

Penentuan main entrance dan side entrance tentu dipengaruhi oleh faktor tertentu diantaranya adalah terkoneksinya entrance dengan jalan raya dan transportasi umum, mudah dikenali, mudah dicapai dan tidak membingungkan. Eksisting yang ada saat ini hanya mengakomodir satu main entrance untuk sekaligus menjalankan fungsi sebagai side entrance. Hal ini tentunya sangat merugikan karena menyebabkan ketidak-lancaran sirkulasi inout Pelabuhan. Oleh karena itulah diperlukan pembedaan fungsi antara main entrance dan side entrance begitupula dengan letaknya pada eksisting.

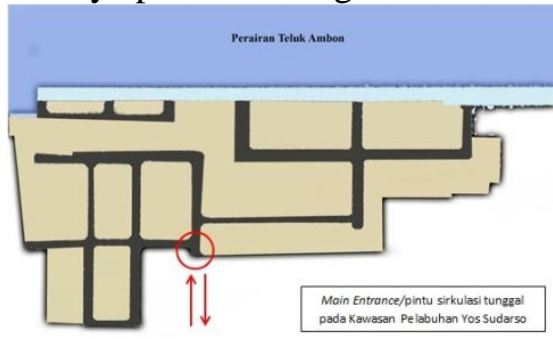

Gambar 25. Ilustrasi letak main entrance yang ada pada eksisting saat ini

Letak main entrance dan side entrance yang ada saat ini akan dirubah untuk mencapai titik kelancaran yang berimbas pada sirkulasi in dan out eksisting. Pembedaan antara main entrance dan side entrance terletak pada peruntukannya, yakni pengguna yang diperbolehkan mengakses dan pengguna yang memiliki keterbatasan dalam mengakses entrance tersebut. Letak main entrance dan side entrance tersebut dapat dijabarkan sebagai berikut :

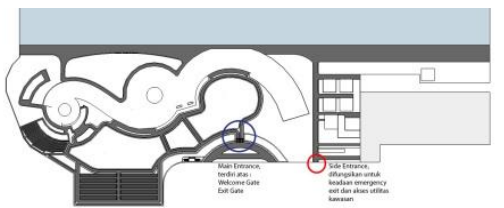

Gambar 26. Ilustrasi letak main entrance dan side entrance yang baru pada eksisting site

g. Penataan Lansekap Kawasan

Analisis penataan lansekap diperlukan untuk memperhitungkan andil lansekap dalam menciptakan kondisi yang diinginkan didalam eksisting. Lansekap yang direncanakan terdiri atas elemen softscape dan hardscape dengan perbandingan 5:1 sesuai dengan perhitungan kebutuhan dasar ruang terbuka. Pemilihan vegetasi disesuaikan dengan kebutuhannya dalam mengatasi thermal berlebih, potensi angin, filter udara serta kebutuhan estetik lingkungan.

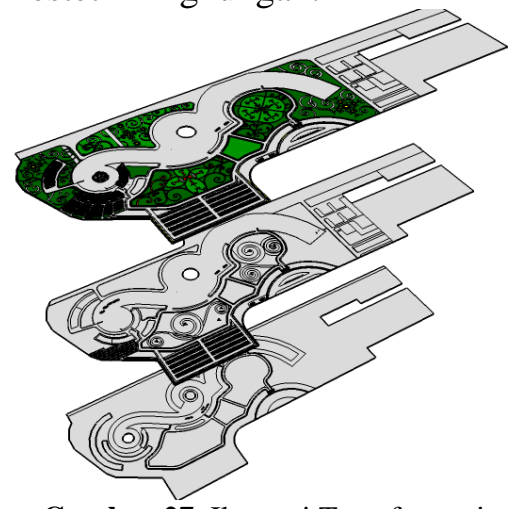

Gambar 27. Ilustrasi Transformasi Penataan Lansekap pada Existing Site

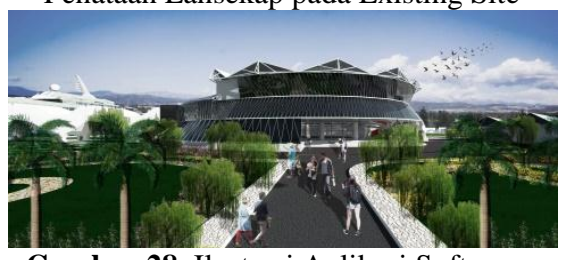

Gambar 28. Ilustrasi Aplikasi Softscape pada lansekap kawasan

Elemen hardscape pada eksisting memanfaatkan jenis material yang mampu menyerap kelebihan air saat musim penghujan tiba dengan mengutamakan sifat porous material. Sedangkan element softscape pada eksisting memanfaatkan 41 
jenis vegetasi dengan 5 peruntukan sesuai dengan sifat masing-masing vegetasi. Keseluruhan elemen dipertimbangkan untuk dapat menghadapi intensitas penyinaran matahari yang berlebih serta bersifat salt-tolerance.

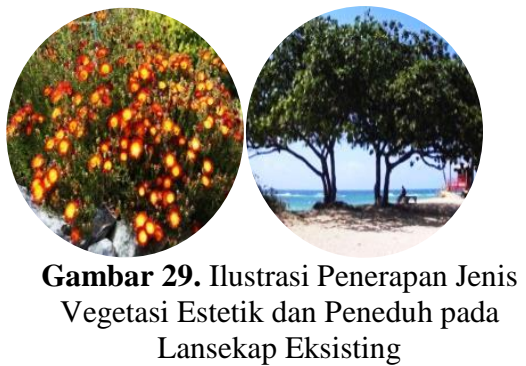

h. Program ruang

Analisa program ruang dilakukan untuk mengetahui kegiatan apa yang berlangsung didalam sebuah objek bangunan, pengguna serta luasan yang perlu untuk diwadahi. Kegiatan yang terdapat didalam Kawasan Pelabuhan Yos Sudarso Ambon antara lain Kegiatan Kepelabuhan (DebarkasiEmbarkasi Penumpang), Kegiatan Kepariwisataan (Transit and Explore Cruise Ship)dan Kegiatan Penunjang (Kegiatan Perkantoran). Sedangkan Pelaku kegiatan secara garis besar dibedakan atas penumpang dan/atau calon penumpang, wisatawan lokal maupun mancanegara, pegawai kepelabuhan, buruh pelabuhan serta masyarakat umum. Selain itu, terkait dengan besaran yang ideal dan sesuai dengan kebutuhan bagi masing-masing ruang, maka dilakukan pertimbangan berdasarkan standar besaran ruang menurut literature. Luasan ruang meliputi :

Tabel 1. Total Kebutuhan Luasan Ruang pada Terminal Penumpang Pelabuhan Yos Sudarso

\begin{tabular}{|l|l|l|}
\hline No. & Zona & Besaran Ruang \\
\hline 1. & $\begin{array}{l}\text { Zona Embarkasi dan } \\
\text { Debarkasi Penumpang \& } \\
\text { Wisatawan }\end{array}$ & $38.294 \mathrm{~m}^{2}$ \\
\hline 2. & Zona Pengelola Pelabuhan & $9.305 \mathrm{~m}^{2}$ \\
\hline 3. & $\begin{array}{l}\text { Zona Fasilitas Penunjang } \\
\text { (Zona Transisi \& Zona } \\
\text { Darat) }\end{array}$ & $135.929 \mathrm{~m}^{2}$ \\
\hline
\end{tabular}

i. Tampilan Fisik

Analisa tampilan fisik digunakan untuk menentukan pemilihan material, mempertimbangkan bukaan untuk mendapatkan pencahayaan alami serta memenuhi karakteristik-karakteristik arsitektur futuristik yang ingin disampaikan.

Untuk memenuhi nilai keringanan pada tampilan fisik, penggunaan material kaca sangat diperhitungkan. Selain memiliki nilai keringanan yang tinggi, kaca juga memiliki poin transparasi sesuai dengan karakteristik arsitektur futuristik, selain itu kaca juga dapat memberikan kesan megah dan luas terhadap suatu bangunan, tahan terhadap biasan air laut (yang mengandung kadar garam tinggi), tidak memisahkan bangunan dengan kawasan karena bersifat tembus pandang. Namun, kaca juga memiliki kelemahan. Diantaranya adalah adanya kemungkinan munculnya gaya getaran akibat bertabrakan dengan potensi angin yang dapat mengakibatkan retakan serta dapat dengan mudah menyerap panas kedalam bangunan. Untuk mengatasi persoalan penggunaan material yang akan mempengaruhi tampilan fisik bangunan, maka dipilihlah kaca dengan jenis laminated glass. Kaca jenis ini mampu untuk menahan tekanan angin yang kuat serta meminimalkan efek getaran dan mampu bertahan terhadap perubahan suhu mendadak. Permasalahan thermal berlebih pada bangunan dapat diatasi dengan penentuan jenis ventilasi udara yang tepat seperti yang sudah dijelaskan sebelumnya.

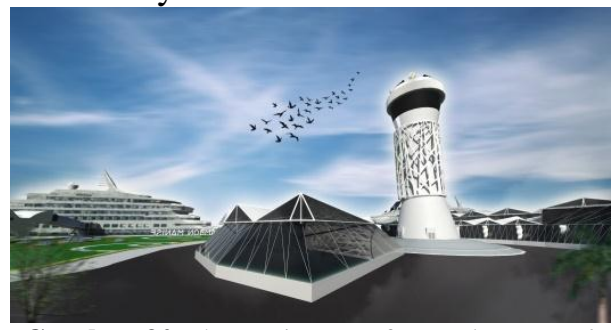

Gambar 30. Ilustrasi pemanfaatan laminated glass pada desain

Pengaplikasian karakter arsitektur futuristik lainnya seperti pemanfaatan garis-garis miring dan elips untuk menciptakan unsur dinamis diperlihatkan pada fasad. Struktur- 
struktur pendukung bangunan tidak disusun secara tegak lurus, melainkan lebih kearah dinamis vertikal, miring serta "berani". Begitupula dengan material pengisi struktur yang berupa kaca, kaca yang digunakan merupakan jenis kaca bending atau curved glass.

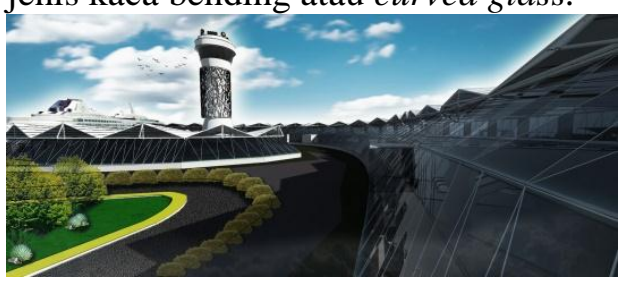

Gambar 31. Ilustrasi pemanfaatan curved glass pada desain

j. Struktur dan Utilitas

Analisa struktur dan utilitas digunakan untuk menentukan struktur utama yang akan digunakan serta sistem utilitas yang mungkin diterapkan hal ini diimplementasikan dengan kebebasan dan keberanian serta menyelaraskan manusia dan lingkungannya sesuai dengan karakteristik arsitektur futuristik.

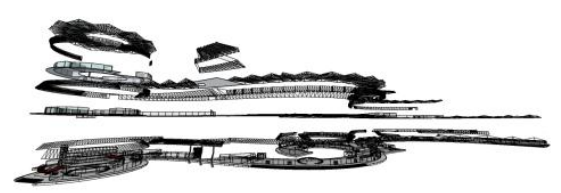

Gambar 32. Ilustrasi I Axonometri Struktur pada Bangunan

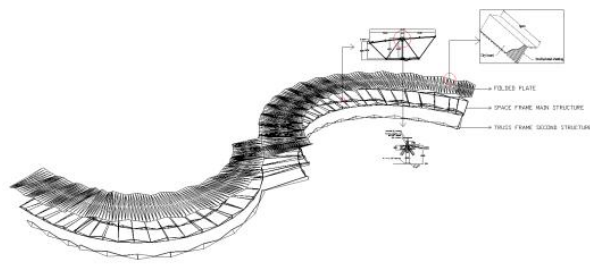

Gambar 33. Ilustrasi II Axonometri Struktur pada Bangunan

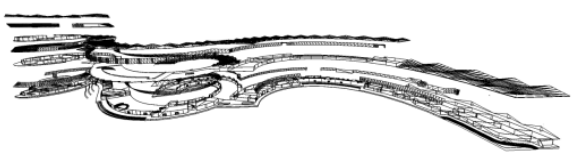

Gambar 34. Ilustrasi III Axonometri Struktur pada Bangunan

Karena karakteristik yang akan diaplikasikan harus disesuaikan dengan pendekatan futuristik yang terkadang dalam perkembangannya dapat menghasilkan bentuk-bentuk bangunan yang "tidak terduga" maka modul struktur yang digunakan, cinderung pada modul struktur campuran. Yakni mengkombinasikan struktur rangka ruang, struktur rangka grid serta struktur permukaan bidang. Sedangkan untuk sistem utilitas yang mungkin diterapkan didalam kawasan dan bangunan adalah merupakan sistem utilitas yang memiliki nilai keramahan terhadap lingkungan disekitarnya dan mengadopsi kemajuan teknologi terbarukan. Seperti underground supply power, automatic landscape sprinkler, dan automatic system for building censor.

\section{KESIMPULAN}

Tapak

Secara garis besar, aplikasi arsitektur futuristik yang ditetapkan pada tapak memanfaatkan asas kecepatan dan on point. Sehingga diharapkan keberadaan objek bangunan tidak saling mengganggu antara satu dan yang lain didalam kawasan. Selain itu, berdasarkan perhitungan yang sudah dilakukan dalam tahap analisis dapat disimpulkan bahwa kebradaan terminal penumpang yang baru memanfaatkan $47 \%$ dari total keseluruhan lahan seluas $38 \mathrm{Ha}$.

\section{Program Ruang}

Program ruang yang diaplikasikan pada objek bertumbuh dari adanya kebutuhan yang meningkat dari tahun ke tahun. Sehingga didapatkanlah kebutuhan luas ruang sebesar $183.528 \mathrm{~m}^{2}$ yang terdiri atas zona embarkasi dan debarkasi, zona pengelola dan zona penunjang.

Tampilan Fisik

Konsep tampilan fisik yang diaplikasikan pada objek memanfaatkan beberapa karakteristik seperti penggunaan garis-garis miring pada fasad bangunan, sehingga menggekpresikan sifat yang dinamis. Penggunaan bahan material yang bersifat ringan dan berkarakter kuat serta mengadopsi bentuk-bentuk geometris dan kombinasi kotak maupun lengkung. 
Struktur dan Utilitas

Konsep struktur utama pada bangunan memanfaatkan modul struktur campuran mengingat bentuk bangunan yang tidak biasa dan didominasi oleh banyak lengkungan. Material bangunan didominasi oleh kaca berpori serta baja yang dilapisi zat tertentu untuk membantu mencegah adanya korosi pada material bangunan. Begitu halnya dengan sistem utilitas, system utilitas yang diterapkan menyangkut utilitas kawasan dan utilitas bangunan yang terdiri atas beberapa konsentrasi utilitas tertentu. Seperti listrik, pencahayaan buatan, penghawaan buatan, suplai air ersih, komunikasi internal, penangkal petir, perlindungan kebakaran, system keamanan serta pengolahan limbah dan sirkulasi vertikal horizontal. Dari hasil analisa serta hasil korelasi dari beberapa data yang sudah dijabarkan diatas, maka diperoleh hasil berupa rancangan sebagai berikut:

Nama objek :Terminal Penumpang Pelabuhan Yos Sudarso

Lokasi : Jl. Yos Sudarso No. 1 Kota Ambon, Provinsi Maluku

Luas Lahan : $388.388 \mathrm{~m}^{2}$

Luas Bangunan : $183.528 \mathrm{~m}^{2}$

Daya Tampung : 3.347 orang

Kegiatan utama :Proses Embarkasi-Debarkasi penumpang pengguna moda transportasi laut dengan cakupan pelayaran lokal, nasional dan mancanegara

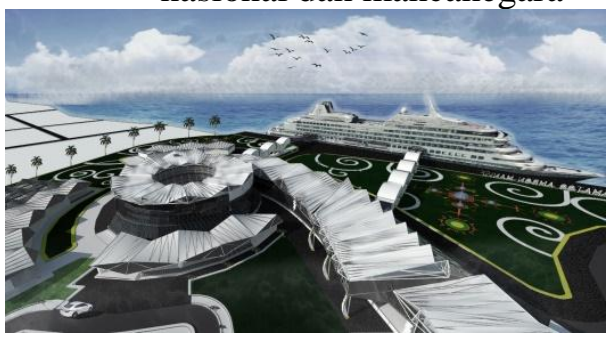

Gambar 35. Perspektif I Eksterior

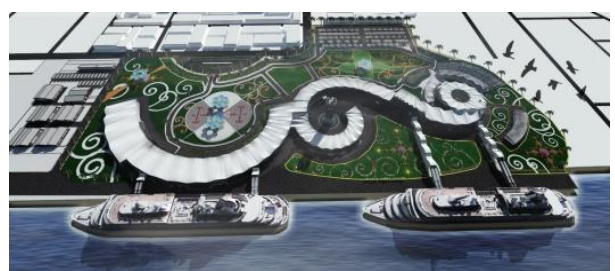

Gambar 36. Perspektif II Eksterior

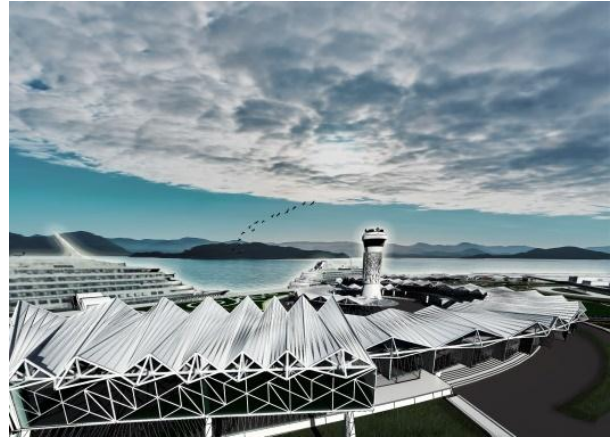

Gambar 37. Perspektif III Eksterior

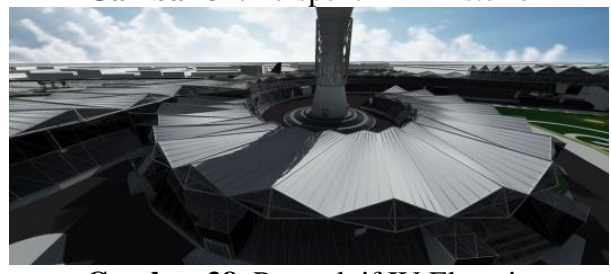

Gambar 38. Perspektif IV Eksterior

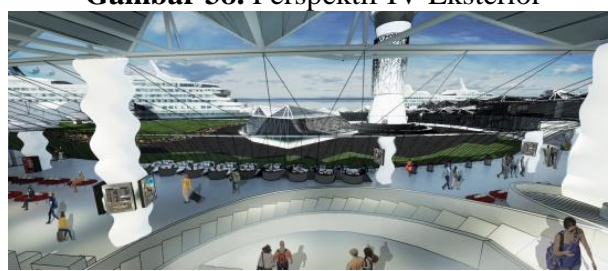

Gambar 39. Perspektif I Interior Hall Embarkasi

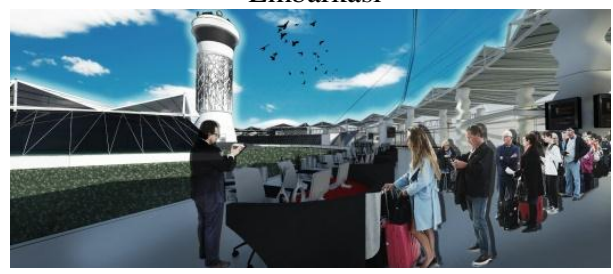

Gambar 40. Perspektif II Interior Hall Embarkasi

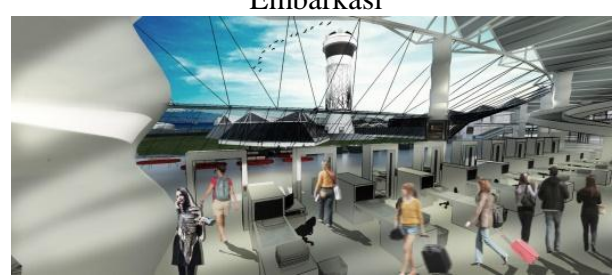

Gambar 41. Perspektif III Interior Hall Embarkasi

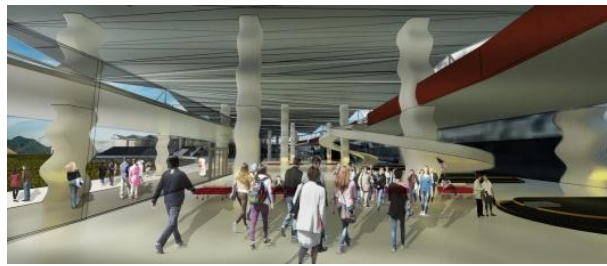

Gambar 42. Perspektif I Interior Hall Debarkasi 


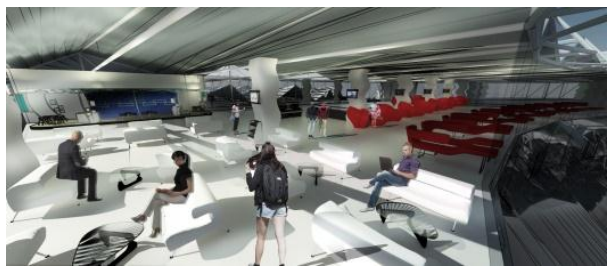

Gambar 43. Perspektif Executive Lounge

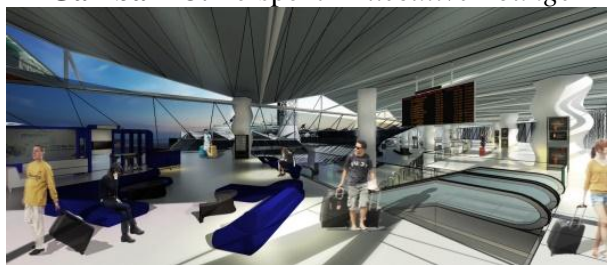

Gambar 44. Perspektif IV Interior Hall Embarkasi

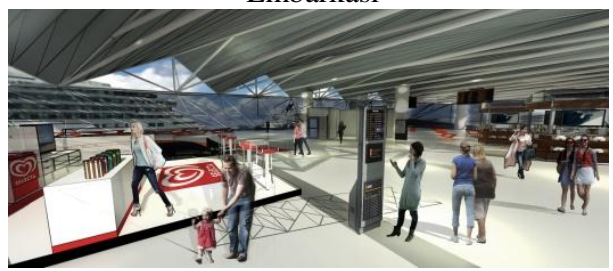

Gambar 45. Perspektif Anjungan Pengantar

\section{REFERENSI}

Aaron Betsky. 1998. Zaha Hadid The Complete Buildings and Projects. Rizzoli. United Kingdom.

Croline Klein. 2011. Vision of Future Living Futuristic. DAAB MEDIA GMBH. Scheidtweilerstrasse Germany.

Klaus Sedlbauer. 2012. Building for The Future-The Future for Building. Fraunhofer Building Innovation Alliance. Fraunhoferstrasse Germany.

Lawrence Rainey, dkk. 2009. .Futurism An Anthology. Kingley Trust Association Publication. United States of America. 